\title{
EFFECT OF HOUSEHOLD DEMOGRAPHICS ON THE TECHNICAL EFFICIENCY OF COWPEA FARMERS: EVIDENCE FROM STOCHASTIC FRONTIER ANALYSIS IN NIGERIA
}

\author{
Coker A.A.A. ${ }^{*}$ Ibrahim F.D., Ibeziako U.N. \\ Department of Agricultural Economics and Extension Technology, \\ Federal University of Technology, Minna, Nigeria \\ *E-mail: ayodejicoker@futminna.edu.ng
}

\begin{abstract}
Technical efficiency of cowpea production in Nigeria has been associated with numerous factors, comprising institutional, production and farmer specific factors. However, outcomes regarding the latter continued to receive attention, given the resource poor nature of farming households. This study therefore examined the effects of household demographics on the technical efficiency of cowpea farmers in Niger State, Nigeria. Data were obtained through structured questionnaires administered to 286 respondents. Descriptive statistics and stochastic frontier analysis model were used for data analysis. The study revealed that household demographics and educational status have direct statistical effects on the technical efficiency of the cowpea farmers. The key challenges witnessed by respondents were lack of credit and low income as reported by 83.22 and $74.83 \%$ of the respondents respectively.
\end{abstract}

\section{KEY WORDS}

Household, demographics, technical efficiency, cowpea, production.

Agriculture is the back bone of Nigeria's economy; as it contributes $23.1 \%$ to the Gross Domestic Product (GDP) and accounts for $38 \%$ of the working population (Federal Ministry of Budget and National Planning, 2017). However, the sector is believed to be one of the country's potential sources of revenue that is still underdeveloped and unexplored. For instance, estimated $80 \%$ of the available land in the country is arable, with potentials for cultivation (Info Guide Nigeria, 2014). The agriculture sector is also dominated by the crop sub-sector, which accounts for about $85 \%$ of the sector, covering cash and arable crops, including cowpea.

Cowpea is a tropical annual herbaceous legume grown majorly in Nigeria and it provides income and employment opportunities for most people in the rural areas of the country. Nigeria is the largest producer in the World, as it produces an estimated 2.17 million tons annually (Food and Agricultural Organization, 2014). However, cowpea production in Nigeria has been sub-optimal, with producers' technical efficiencies below the frontier in most parts of the country. In most cases, resources were either under or over-utilised (Sofoluwe and Kareem, 2011; Egbetokun and Ajijola, 2008; Abba, 2016 and Abdui, Makama and Mika 'il, 2013). However, while affirming that traditional farms are characterised by low use of purchased inputs other than labour and associated with low yields, Norton, Alwang and Masters (2015) argued that traditional farms tend to be poor, but efficient. This controversy remained largely unresolved in-spite the dynamic nature of the study of economics.

Demographics on the other hand, involves the study of specific population based on factors ranging from age, sex, to their hobbies and lifestyles in order to be able to characterize and assess the behaviour of the population (igi-global dictionary). Expectedly, these specific characteristics play key roles in farmers' production activities from whatever perspective it is being viewed. Sofoluwe and Kareem, 2011; Abba, 2016 have established the effect of farmers' demographics on technical efficiency. Given the associated factors impinging on farmers' efficiency under cowpea production in the study area, there are doubts, whether farmers' demographics have any meaningful effect on farmers' technical efficiency. Thus, a pertinent question to ask therefore is whether demographic composition 
has an effect on farmers' technical efficiencies. Therefore, this study described the demographic characteristics of cowpea farmers in the study area, assessed the effect of household demographics on the technical efficiency of respondents and identified challenges limiting cowpea production in the study area.

Basically, the initial discourse on efficiency stems from equity consideration and was premised on three theories, namely the Pareto Efficiency or Pareto Optimality, the KaldorHicks improvement and the Zero Profit Condition or Zero Profit Theorem (Intelligent economist). While Pareto optimality theory was premised on making one individual better off without making any other worse off (termed Pareto Efficient), Kaldor-Hicks Efficiency was based on logic that Pareto Optimal outcome can be reached by arranging sufficient compensation from those who are made better off to those who are made worse off. Zero Profit Theorem on the other hand, states that entry into a compatible industry will continue until all opportunity for positive economic profit is reduced to zero. With the pioneering work by Farell however, efficiency theories have focused on input output relationships, output optimization, given a set of input prices, productivity, performance, quality and profit. Also, the trend in efficiency estimation has gone from double to single model estimation, using either the parametric and or the non-parametric approaches. However, recent insight differentiated between productivity and efficiency, with the former viewed from the current rhetoric of output optimization from a set of inputs, while the latter was viewed from the perspective of optimal resource allocation (Norton, Alwang and Masters, 2015), with the resolve that smallholder farmers are associated with low productivity but are largely efficient in terms of resource allocation. Thus, Farell identified three forms of efficiency, namely technical, allocative and economic efficiencies. Technical efficiency is the ability of a firm to produce a given level of output with a given minimum quantity of input under certain technology. Allocative efficiency on the other hand relates to choosing an optimal set of inputs with given set of input prices. Economic is a product of the technical and allocative efficiencies and relates to the concept productivity, performance, quality and profit. This study draws mainly from Farrell's efficiency theories with focus on the technical efficiency.

\section{METHODS OF RESEARCH}

The study was carried out in Niger State, situated in the North Central of Nigeria. The state lies in the Guinea Savannah Vegetation Zone and is located within Latitudes $8^{0} 11^{\prime} \mathrm{N}$ and $11^{\circ} 20^{\prime} \mathrm{N}$ and Longitudes $4^{\circ} 30^{\prime} \mathrm{E}$ and $7^{\circ} 20^{\prime} \mathrm{E}$. Niger is bordered to the north by Zamfara State, to the northwest by Kebbi State, to the south by Kogi State, to southwest by Kwara State; while Kaduna State and the Federal Capital Territory borders the State to northwest and southwest respectively. The State also shares a common international boundary with the Republic of Benin at Babanna in Borgu Local Government Area (LGA). Niger State consists of twenty five LGAs grouped into three administrative Zones, namely 1, 2 and 3; with the zones having 8, 8 and 9 LGAs respectively. This study was conducted in Zones 1 and 3 of Niger State. Agriculture is predominant in the state, with cowpea, rice, yam, sugar cane, maize and millet, being the major crops grown.

A multi-stage sampling technique was used for this study. The first stage was a purposive selection of Zones 1 and 3 out of the three Zones in the State, given the preponderance of cowpea farmers (Niger State Agricultural Mechanization and Development Agency, 2016). The second stage was a selection of two LGAs ach from the two Zones. The third stage was the random selection of 2 villages from each of the selected LGA, giving a total of eight villages. In the fourth stage, sampling of farm households in each village was determined proportionately using Yamane's model (Equation 1).

$$
n=\frac{N}{1+N(e)^{2}}
$$

Where: $\mathrm{n}=$ Sample size to be determined; $\mathrm{N}=$ Population size; $\mathrm{e}=$ limit of tolerable error (precision level $=0.05$ ); 1 = constant. 
The data for the study were generated through primary sources and were collected with the use of structured questionnaire designed in line with the research objectives. This was administered to the respondents with the assistance of trained enumerators. Data collected were majorly demographic and input-output data covering variables like age, marital status, household size, household decision maker, while the input-output data covers production inputs used for cowpea production- land, seed, fertilizer, labour, capital, output of cowpea, among others.

Descriptive statistics such as frequency distribution tables, percentages and mean were used to describe and characterize the respondents and identify the challenges to cowpea enterprise, while the Stochastic Frontier Analysis was used to determine the effect of household demographics the technical efficiency of cowpea farmers.

The explicit form of the model is expressed as:

$$
\ln Y=\ln \beta_{0}+\beta_{1} \ln X_{1}+\beta_{2} \ln X_{2}+\beta_{3} \ln X_{3}+\beta_{4} \ln X_{4} \ldots . \beta_{7} \ln X_{7}+(V i-U i)
$$

Where: In is natural logarithm; $\beta_{0}=$ Constant; $\beta_{1-} \beta_{7}=$ Coefficients of production factors to be estimated; $\left(V_{i}-U_{i}\right)=$ Composite error term; $Y=$ Output of Cowpea $(\mathrm{Kg}) ; X_{1}=$ Farm size under cowpea $(\mathrm{Ha}) ; X_{2}=$ Quantity of fertilizer $(\mathrm{Kg}) ; X_{3}=$ Family labour (Man-days); $X_{4}=$ Hired labour (Man-days); $X_{5}=$ Agrochemicals (Litres); $X_{6}=$ Capital inputs (depreciation on fixed cost items such as hoes, cutlasses ( $) ; X_{7}=$ Seed used $(\mathrm{Kg})$.

The effect of household demographics was determined using the inefficiency function specified thus:

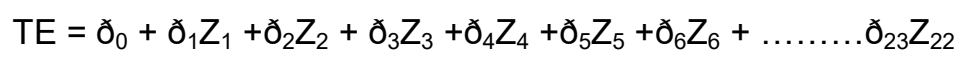

Where: $Z_{1}=$ Household size (Number of persons in the $\mathrm{HH}$ ); $Z_{2}=$ Gender of $\mathrm{HH}$ head (Male $=1$, Female $=0$ ); $Z_{3}=$ Marital Status (Single Yes $=1$, No $=0$ ); $Z_{4}=$ Marital Status (Married Yes =1, No =0); $Z_{5}=$ Marital Status (Divorced $Y e s=1$, No =0); $Z_{6}=$ Age of decision maker on technology utilization (Years); $Z_{7}=$ Gender of decision maker on technology utilization (Male $=1$, Female $=0$ ); $Z_{8}=$ Years of farming experience (Number of years); $Z_{9}=$ Educational level (Number of years spent in formal school); $Z_{10}=$ Farm size (Hectares); $Z_{11}=$ Employment (Number of those employed in the $\mathrm{HH}$ ); $Z_{12}=$ Household Composition Adult male (Number); $Z_{13}=$ Household Composition -Adult female (Number); $Z_{14}=$ Household Composition -Children (Number); $Z_{15}=$ Number of extension visits (Number) $Z_{16}=$ Membership of Cooperative society (Yes $=1$, No $=0$ ); $Z_{17}=$ Number of languages spoken (Number); $Z_{18}=$ House ownership (Male =1, Female =0); $Z_{19}=$ Income of Household Head (Naira); $Z_{20}=$ Access to Credit (Yes =1, No $=0$ ); $Z_{21}=$ Access to insurance (Yes $=1$, No $=0$ ); $Z_{22}=$ Technology Utilization (Index); $\partial_{0}=$ Constant; $\partial_{1}-\partial_{22}=$ Coefficients to be estimated.

\section{RESULTS AND DISCUSSION}

Demographic characteristics of respondents. Table 1 shows that most $(79.75 \%)$ of the farmers in the study area were between the ages of 20 and 50 years, with mean age of 45 years. People within this age range are believed to be in their active ages, implying that the farmers are capable of high productivity and are likely to utilize new technologies. This is in consonance with outcome of the study by Okwwoche et al. (2010), who pointed out that younger farmers are more susceptible to utilize new technologies than older farmers. In all, $76.92 \%$ of the sampled respondents were males and the decision makers of their households. Most $(89.88 \%)$ of the respondents have one educational qualification or the other. The implication is that most of the respondents are literate, with their educational status expected to aid them in applying new technologies. Kimenye (2001) and Nkonya et al, (1997) reported that education have positive and significant relationship with technology utilization. The results from Table 1 further shows that $48.25 \%$ of the farmers have between 1.0 ha and 1.9 ha, with a mean of 0.9 ha. This indicates that the respondents are small-scale 
producers, with obvious implications for enterprise scale and commercialization. However, Fasasi (2007) noted that the small scale farmers are responsible for the bulk of the food produced in Nigeria. Most (56.3\%) of the respondents had household comprising $6-11$ persons. The mean household size was 10, implication that, respondents on the average maintain large family sizes. This could be an asset for family labour, although extra expenses may be incurred with respect to feeding, health and education. According to Perz (2003), a large household may encourage utilization of labour-intensive improved inputs. Farmers with $6-10$ years experience $(39.15 \%)$ predominate and this is followed by $23.78 \%$ of farmers with 11-15 years experience.

Table 1 - Distribution of respondents according to household demographics

\begin{tabular}{lcccc}
\hline \multicolumn{1}{c}{ Variables } & Frequency & Percentage & Mean & Standard Deviation \\
\hline Age & 21 & & & \\
$<31$ & 97 & 7.35 & 44.6 & \\
$31-40$ & 110 & 38.92 & & \\
$41-50$ & 56 & 19.59 & & \\
$51-60$ & 2 & 0.70 & & \\
61 and above & 220 & 76.92 & & \\
Decision maker & 66 & 23.08 & & \\
Male & & & & \\
Female & 29 & 10.14 & & \\
Educational level & 173 & 60.50 & & \\
(Number of years spent) & 67 & 23.43 & & \\
0 & 17 & 5.95 & & \\
$1-6$ & & & & \\
$7-12$ & 102 & 35.67 & 0.9 & \\
13 and above & 138 & 48.25 & & \\
& 42 & 14.69 & & \\
Farm Size & 4 & 1.40 & & \\
$0.1-0.9$ & & & \\
$1.0-1.9$ & 31 & 10.84 & 10 & \\
$2.0-2.9$ & 161 & 56.3 & & \\
$3.0>$ & 82 & 28.67 & & \\
Household Size & 12 & 4.2 & & \\
$<6$ & 0 & 0 & \\
$6-11$ & & & \\
$12-17$ & & & \\
$18-23$ & & & \\
$>23$ & & & & \\
\hline
\end{tabular}

Source: Field Survey, 2016.

Effect of Household Demographics on the Technical Efficiency of Cowpea Farmers. The estimated coefficients of the Stochastic Frontier Analysis as presented in Table 2 shows that the estimated sigma-square (0.19) and gamma estimate $(0.99)$ were significant at $1 \%$ level of probability. The latter shows that, there was $99 \%$ variation in output resulting from technical inefficiencies of the farmers. The estimate of the parameters of the stochastic production frontier indicated that the coefficients of all the significant factors included in the efficiency function were positive, implying that increase in the use of any of the factors led to increase in technical efficiency, cetris paribus.

Specifically, inputs with respect to farm size, hired labour, agrochemicals and seed were all positive and statistically significant at $1 \%$ level of probability implying that an increase of $1 \%$ in these inputs resulted in an increase in output by $0.753 \%, 0.013 \%, 0.049 \%$ and $0.043 \%$ respectively. This aligns with the outcomes of studies by Bekele (2003), Boris et al, (1997), Nyagaka et al, (2010) and Agwu (2004).

With respect to the inefficiency model, gender of household head was positive with coefficient of 0.471 , which was statistically significant at $5 \%$ level of probability. The implication is that gender of household does not increase efficiency. Farm size was negative with coefficient of -0.149 which was also statistically significant at $5 \%$. The implication is that farm size increase efficiency. This is in line with Boris et al. (1997) and Tanko et al. (2008) 
that reported that farm size has a significant influence on farmers' efficiency, but in contrast with the study of Akinwumi et al. (1996) that reported that farm size has no influence on farmers' efficiencies. Educational level was positive and statistically significant at $10 \%$ with a coefficient of 0.011 , implying that educational level does not increase efficiency. This runs contrary to the studies of Kimenye (2001), Mendola (2007) and Okoye et al. (2006) who reported that education promoted farmers' efficiency. The coefficients of being single and divorced were positive with values 0.432 and 0.408 respectively and significant at $1 \%$ level of probability while being married was negative with coefficient -0.316 and also significant at $1 \%$ level of probability. This implies that marriage increases efficiency. This may be as a result of the advantage of the combined efforts of married people in acquiring agricultural information and pulling funds together to utilize technologies as against those of respondents that were single and divorced. Gender of decision maker on technology utilization, employment, number of extension visits, house ownership, income of household head and access to credit were significant at $1 \%$ level of probability and negative with coefficients $-0.096,-0.190$, $0.654,-0.000$ and -0.919 respectively. This implies that these variables increase efficiency.

Table 2 - Effects by household demographics on respondents' technical efficiency

\begin{tabular}{|c|c|c|c|c|}
\hline Variables & Parameter & Coefficient & Standard-error & t-ratio \\
\hline \multicolumn{5}{|l|}{ Efficiency model } \\
\hline Constant & ð0 & 7.669717 & 0.596637 & $12.85^{\star \star *}$ \\
\hline Farm size & ð1 & 0.753937 & 0.018543 & $40.66^{* * *}$ \\
\hline Fertilizer & ð2 & 0.001615 & 0.001688 & 0.96 \\
\hline Family labour & ð3 & 0.004146 & 0.002880 & 1.44 \\
\hline Hired labour & ð4 & 0.013527 & 0.001918 & $7.05^{\star * *}$ \\
\hline Agrochemicals & ð5 & 0.049946 & 0.006792 & $7.35^{\star * *}$ \\
\hline Capital inputs & ð6 & 0.148705 & 0.085850 & 1.73 \\
\hline Seed & ð7 & 0.043970 & 0.016770 & $2.62^{* \star *}$ \\
\hline \multicolumn{5}{|l|}{ Inefficiency model } \\
\hline Constant & ð0 & 2.391503 & 0.396236 & $6.04^{* * *}$ \\
\hline Household size & ð1 & -0.024572 & 0.128653 & -0.19 \\
\hline Gender of $\mathrm{HH}$ head & ð2 & 0.471671 & 0.183052 & $2.58^{* *}$ \\
\hline Marital status - single & ð3 & 0.432319 & 0.100134 & $4.32^{* * *}$ \\
\hline Marital status - married & ð4 & -0.316448 & 0.088266 & $-3.59^{* * *}$ \\
\hline Marital status - divorced & ð5 & 0.408890 & 0.101565 & $4.03^{* * *}$ \\
\hline Age of decision maker on technology utilization & ð6 & -0.004401 & 0.004860 & -0.91 \\
\hline Gender of decision maker on technology utilization & ð7 & -0.736329 & 0.113748 & $-6.47^{* * *}$ \\
\hline Years of farming experience & ð8 & 0.005219 & 0.007013 & 0.74 \\
\hline Educational level & ð9 & 0.011691 & 0.006355 & $1.84^{*}$ \\
\hline Farm size & ð10 & -0.149852 & 0.060949 & $-2.46^{* *}$ \\
\hline Employment & ð11 & -0.096400 & 0.025215 & $-3.82^{* * *}$ \\
\hline HH Composition - Adult male & ð12 & -0.025457 & 0.131227 & -0.19 \\
\hline HH Composition - Adult female & ð13 & 0.131568 & 0.131523 & 1.00 \\
\hline HH Composition - Children & ð14 & 0.050560 & 0.128153 & 0.39 \\
\hline Number of extension visits per production season & ð15 & -0.190364 & 0.046078 & $-4.13^{\star * *}$ \\
\hline Membership of Cooperative society & ð16 & -0.087049 & 0.093143 & -0.93 \\
\hline Number of languages spoken & ð17 & -0.079570 & 0.050572 & -1.57 \\
\hline House ownership & ð18 & -0.654500 & 0.131643 & $-4.97^{* * *}$ \\
\hline Income of Household Head & ð19 & -0.000016 & 0.000002 & $-9.62^{* * *}$ \\
\hline Access to Credit & ð20 & -0.919833 & 0.144010 & $-6.39^{* * *}$ \\
\hline Access to insurance & ð21 & -0.113649 & 0.125463 & -0.91 \\
\hline Technology Utilization & ð22 & 0.459189 & 0.140217 & $3.27^{\star * *}$ \\
\hline Sigma-squared & $\sigma^{2}$ & 0.191528 & 0.029841 & $6.42^{* * *}$ \\
\hline Gamma & $\Gamma$ & 0.996769 & 0.001083 & $920.13^{* * *}$ \\
\hline
\end{tabular}

Log likelihood function $=149.55944^{* * *} L R$ test of the one-sided error $=294.69447^{* * *}$

*** Significant at 1\%, ${ }^{* *}$ significant at $5 \%$, * significant at $10 \%$

Source: Computation from survey data, 2016

This agrees with the studies of Katungi (2006), Habtemariam (2004), Boris et al. (1997), Kidane (2001), Getahun (2004), Mbanasor et al. (2008), David (2005) and Okoye et al. (2006). Technology utilization was positive with coefficients 0.459 and was statistically significant at $1 \%$ level of probability, implying that technology utilization decreases efficiency. 
This could be as result of inadequate and wrong utilization, arising from inadequate knowledge.

The frequency distribution of technical efficiency levels for cowpea farmers in the study area is presented in Table 3 . The mean technical efficiency was 0.791 , which suggested that on the average, the observed cowpea output was $21 \%$ less than the optimum output. This implies that the cowpea farmers on the average were technically efficient $(0.791)$ and were $21 \%$ below the frontier due to technical inefficiency. This situation can be enhanced by adopting best practices of existing technologies. The result further indicates that technical efficiency indices range from $44 \%$ to $96 \%$ for the study area, with an average of $79 \%$.

Table 3 - Technical efficiency distribution of Cowpea farmers in Niger State

\begin{tabular}{lll}
\hline Technical Efficiency Score & Frequency & Percentage \\
\hline $0.31-0.40$ & 47 & 16.43 \\
$0.41-0.50$ & 1 & 0.35 \\
$0.51-0.60$ & 11 & 3.85 \\
$0.61-0.70$ & 31 & 10.84 \\
$0.71-0.80$ & 15 & 5.24 \\
$0.81-0.90$ & 38 & 13.29 \\
$0.91-1.00$ & 143 & 50.00 \\
Sample size & 286 & 100.00 \\
Minimum score & 0.445 & \\
Maximum score & 0.9622 & \\
Mean score & 0.791 & \\
\hline
\end{tabular}

Source: Computation from survey data, 2016.

Challenges to Cowpea Production. The key challenges hindering cowpea production in the study area were lack of credit $(83.22 \%)$, low income $(74.83 \%)$, high cost of hired labour $(74.83 \%)$, risk of new technology $(64.69 \%)$, complexity of technology $(60.84 \%)$ and limited knowledge of equipment use (57.34\%) (Table 4).

Table 4 - Challenges hindering Cowpea production

\begin{tabular}{lll}
\hline Challenges & Frequency & Percentage \\
\hline Risk of new technology & 185 & 64.69 \\
Complexity of technology & 174 & 60.84 \\
Doubts in Profitability & 44 & 15.38 \\
Lack of credit & 238 & 83.22 \\
Low income & 214 & 74.83 \\
Low accessibility & 90 & 31.70 \\
Language barrier & 30 & 10.49 \\
Insufficient training & 50 & 17.48 \\
Societal factors & 65 & 22.73 \\
Religious inclination & 47 & 16.43 \\
Cultural inclination & 68 & 23.78 \\
Little knowledge of equipment usage & 164 & 57.34 \\
Little or no experience in cowpea farming & 77 & 26.92 \\
Doubts in efficiency of equipment & 113 & 39.51 \\
Use of hired labour & 152 & 53.15 \\
Large size of land cultivated & 128 & 44.76 \\
\hline
\end{tabular}

Source: Computation from survey data, 2016.

\section{CONCLUSION AND RECOMMENDATIONS}

On the basis of the outcome of this study, the study concluded that some household demographics had significant effect on the efficiency of cowpea production in the study area. Consequently, the study recommended as follows:

The need to encourage married people into cowpea production, given the benefits in pooling resources together to obtain efficiency inducing technologies; 
Without prejudice to the emphasis on productivity and given the untapped arable land resources, it is imperative for the Niger State Agricultural Mechanization and Development Authority to create awareness for acreage expansion in order to enhance the efficiency of cowpea farmers.

Given the importance of asset ownership in household empowerment and efficiency enhancement, there is the need to support technologies that will raise cowpea returns on investment with a view to enhancing the acquisition of relevant assets and adequately position cowpea farmers for investment in their cowpea enterprise; and

It is imperative for policy makers in the state to take cognizance of farmers' demographic characteristics in policies relating to cowpea improvement in the study area.

\section{REFERENCES}

1. Abba, M.W. (2016). Economic Analysis of Cowpea Production in Nigeria. Russian Journal of Agricultural and Socio-economic Sciences, 1(13).

2. Abdui, Z., Makama, S.A. and Mika'il, K.T. (2015). Resource Use Efficiency in SmallScale Cowpea Production System in Dawakin Kudu Local Government Area, Kano State, Nigeria. Journal of Agriculture and Sustainability. Vol. 8, No. 2, 69-82.

3. Akinwumi, A.A., \& Djato, K. K. (1996). Farm Size Relative Efficiency and Agrarian Policy in Cote d'Ivoire: Profit Function Analysis of Rice Farms. Cote d'Ivoire. Agricultural Economics, 30-39.

4. Agwu, A.E. (2004). Factors influencing adoption of improved cowpea production technologies in Nigeria. Journal of International Agricultural Extension Education, 11(1):81-88.

5. Bekele, A. (2003). Effect of Farm Size on Technical Efficiency: A Case Study of the Moretna - Jirru District in Central Ethiopia. Unpublished PhD Thesis, Department of Agricultural Economics. University of the Free State, Bloemfontein, South Africa. 1-230.

6. Boris, E., Bravo-Ureta., \& Pinheiro, E.A. (1997). Technical, Economic And Allocative Efficiency in Peasant Farming: Evidence from the Dominican Republic. Developmental Economics, 35(1), 48-67.

7. David, R. Lee (2005). Agricultural Sustainability and Technology Adoption: Issues and Policies for Developing Countries. American Journal of Agricultural Economics , 20-24.

8. Egetokun, A.O. and Ajijola, S. (2008). Technical Efficiency of Cowpea Production in Osun State, Nigeria. Continental Journal of Agricultural Economics 2: 32-37. Wiloud Online Journals.

9. Federal Ministry of Budget and National Planning, (2017). Economic Recovery and Growth Plan 2017-2020, Abuja, Nigeria.

10. Food and Agriculture Organization (FAO), (2014). How to grow a good cowpea crop in Nigeria. Accessed June, 2014 from http://www.fao.org/sd/erp/ toolkit/ books/cowpea_illust_guidebook.pdf. and en.wikipedia.org/wiki/rimi_Nigeria

11. Getahun, D. (2004). Assessment of Factors Affecting Adoption of Wheat Technologies and Its Impact: The Case of Hula Woreda, Ethiopia. MSc. Thesis (Unpublished) Presented To School of Graduate Studies of Alemaya University, 1. Ethiopia.

12. Infoguidenigeria.com/role-agriculture-Nigeria's-economy/ Retrieved 3rd May, 2016.

13. Katungi, E. (2006). Gender, Social Capital and Information Exchange in Rural Uganda IFPRI and Melinda Smale, IFPRI (International Food Policy Research Institute) CAPRi Working Paper No. 59, University of Pretoria. SouthAfrica.[Online]. http://www.capri.cgiar.org/pdf/capriwp59.pdf.Accessed March 31, 2016.

14. Kidane, G. (2001). Factors Influencing the Adoption of New Wheat and Maize Varieties in Tigray, Ethiopia: The Case of Hawzien Woreda. M.S.C. Thesis Presented To School Of Graduate Studies Of Alemaya University, Ethiopia. 140.

15. Kimenye, L. N. (2001). Understanding low rate of technology adoption by women farmers. A case study of the determinant of adoption of improved varieties by women farmers in mbere District, Kenya Journal of Agricultural Statistics 3(1), 204-215. 
16. Mendola, M. (2007). Agricultural technology adoption and poverty reduction: a propensity score matching analysis for rural Bangladesh Food Policy. 32, 2007, 391, 372-393.

17. Mbanasor, J.A., \& Kalu, K.C. (2008). Economic Efficiency of Commercial Vegetable Production System in Akwa Ibom State, Nigeria: A Translog Stochastic Frontier Cost Function Approach. Tropical and Subtropical Agrosystems, 8(3), 313-318.

18. Niger State Agricultural and Mechanization Development Authority (NAMDA) (2012). Impact study final report, Minna, Nigeria, 128.

19. Nyagaka, D.O., Obare, G.A., Omiti, J.M., \& Wilson, N. (2010). Technical Efficiency in Resource Use: Evidence from Smallholder Irish Potato Farmers in Nyandarua North District, Kenya. African Journal of Agricultural Research 5(11). 1179-1186.

20. Okoye, B.C., Onyenweaku, C.E., \& Asumugha, G.N. (2006). Allocative Efficiency of Smallholder cocoyam Farmers in Anambra State, Nigeria. Agricultural Journal 4(38). $70-$ 81.

21. Sofoluwe, N and Kareem, R. (2011). Technical Efficiency of Cowpea Producction in Osun State, Nigeria. Journal of Natural Sciences Research. Vol.1. No.2.

22. Tanko, L., \& Jirgi, A.J. (2008). Economic efficiency among small holder arable crop farmers in Kebbi state, Nigeria. Continental Journal of Agricultural Economics 2. 4-22.

23. https://www.cia.gov//library/publication/the-world-factbook/fields/2012.html; Retrieved 7th November, 2017. 